\title{
Of Hearths and Houses
}

Tom Middlebrook

Heritage Research Center, Stephen F. Austin State University

\section{Ryan Middlebrook}

Follow this and additional works at: https://scholarworks.sfasu.edu/ita

Part of the American Material Culture Commons, Archaeological Anthropology Commons, Environmental Studies Commons, Other American Studies Commons, Other Arts and Humanities Commons, Other History of Art, Architecture, and Archaeology Commons, and the United States History Commons

Tell us how this article helped you.

This Article is brought to you for free and open access by the Center for Regional Heritage Research at SFA ScholarWorks. It has been accepted for inclusion in Index of Texas Archaeology: Open Access Gray Literature from the Lone Star State by an authorized editor of SFA ScholarWorks. For more information, please contact cdsscholarworks@sfasu.edu. 


\section{Of Hearths and Houses}

Creative Commons License

(c) $($ i) (9)

This work is licensed under a Creative Commons Attribution-NonCommercial 4.0 International License 


\title{
OF HEARTHS AND HOUSES
}

\author{
Tom Middlebrook and Ryan Middlebrook
}

\section{INTRODUCTION}

During the 1993 East Texas Archeological Field School conducted at the Tyson site (41SY92) in western Shelby County, the junior author had an opportunity to participate in the excavation of a Caddoan hearth. The work was directed by Linda Lindsay, a graduate student in Anthropology at Southem Methodist University. This paper describes our findings and a few features of hearths and houses.

One goal of the 1993 Field School was to explore the area around Feature 3 looking for evidence of a house. This was accomplished by opening a 6 meter by 6 meter unit referred to as Block 1. Feature 3 had been excavated in 1992 and found to be a 1.2 meter in diameter, round, basin shaped pit containing a large amount of daub, bone, and Caddoan pottery sherds. Near the bottom of the pit was a zone of ash. Charcoal and mussel shell from Feature 3 yielded three calibrated radiocarbon dates of about $1425 \mathrm{AD}$ (Middlebrook 1993).

When Block 1 was completely exposed, a number of other pits and postholes were seen in plan view (Figure 1). Our activity focused on Feature 9 on the western edge of Block 1. This 1.15 meter by 0.9 meter oval hearth was first revealed at $20 \mathrm{~cm}$ depth when ash was encoun- tered (Figure 2). The feature contained large amounts of ash from in situ burning, nuggets of fired clay, a small amount of bone, and several burned sherds with ash adhering to their surfaces. The hearth was slightly basin-shaped and approximately $15 \mathrm{~cm}$ thick. A discontinuous thin layer of bright orange clay near its bottom was observed. The hearth had been prepared for use by digging a very shallow pit but no intentional "clay lining" was seen. Two large postholes were found in the area of Feature 9. Feature 17 was discovered beneath the eastern end of the hearth. It was $30 \mathrm{~cm}$ in diameter and had a smoothly rounded bottom at $75 \mathrm{~cm}$ below ground surface. Feature 12 was a very distinct posthole of similar proportions just west of the hearth. The diameter of F12 was $27 \mathrm{~cm}$ and the depth was $65 \mathrm{~cm}$ below surface.

How do we understand this feature? Specifically, does Feature 9 represent the central hearth of a Caddoan house? This question is currently difficult to answer because the outside wall of a putative house has not been identified. Possibly, Block 1 lies entirely inside a large house. The question may be easier to answer after reviewing accounts written by early Europeans visiting the area and reviewing the archeological findings at other East Texas Caddoan sites.

\section{ETHNOHISTORIC RECORD}

Early Spanish writers described for us the amazingly rapid construction of Caddoan houses; these buildings were often completed in less than a day by many members of the community su- pervised and directed by their goveming elites (Bolton 1987; Swanton 1942; Wyckoff \& Baugh 1980). The initial stage of construction involved the placement of tall poles in a circle around a 
TYSON SITE

(41 SY 92)

Area of Block 1

1993 E. T. Field School

Posthole

Pit

E Hearth

Burial

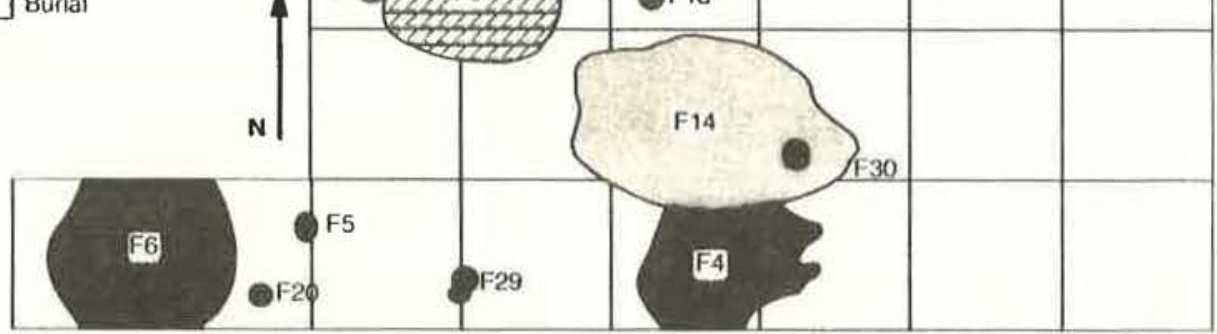

Figure 1. Plan View of Block 1, Tyson Site (41SY92).

removable central post or tree and then pulling the poles together at the top. Espinoza (Hatcher 1927; quoted in Jackson 1936) discusses this:

The laths are placed in a circle and in the middle they put up a very tall pole with knots on it for climbing. Two Indians are placed on top. . . They continue to tie them until they have formed a figure like a half-orange. . They work so dexterously that a little after midday they are finishing the hut. . The building finished, they cut the middle post at the bottom and the building is thus left standing...
There are additional indications in early accounts that the location of the removed central post was subsequently used for a fireplace. While references are made to fires inside ordinary Caddoan houses, the most detailed descriptions involve the fireplaces inside the residences of important religious figures and in special temples. Fire had possibly both functional and sacred significance to the Caddos of East Texas. The homage paid to fire is reflected in these quotations from Morfi (Chabot 1932 in Jackson 1936) and Hidalgo (Hatcher 1927 in Jackson 1936):

Both the former and the latter fear that the fire will get angry with them; and to 


\section{Tyson Site (41SY92) Block 1 Feature 9: Hearth}

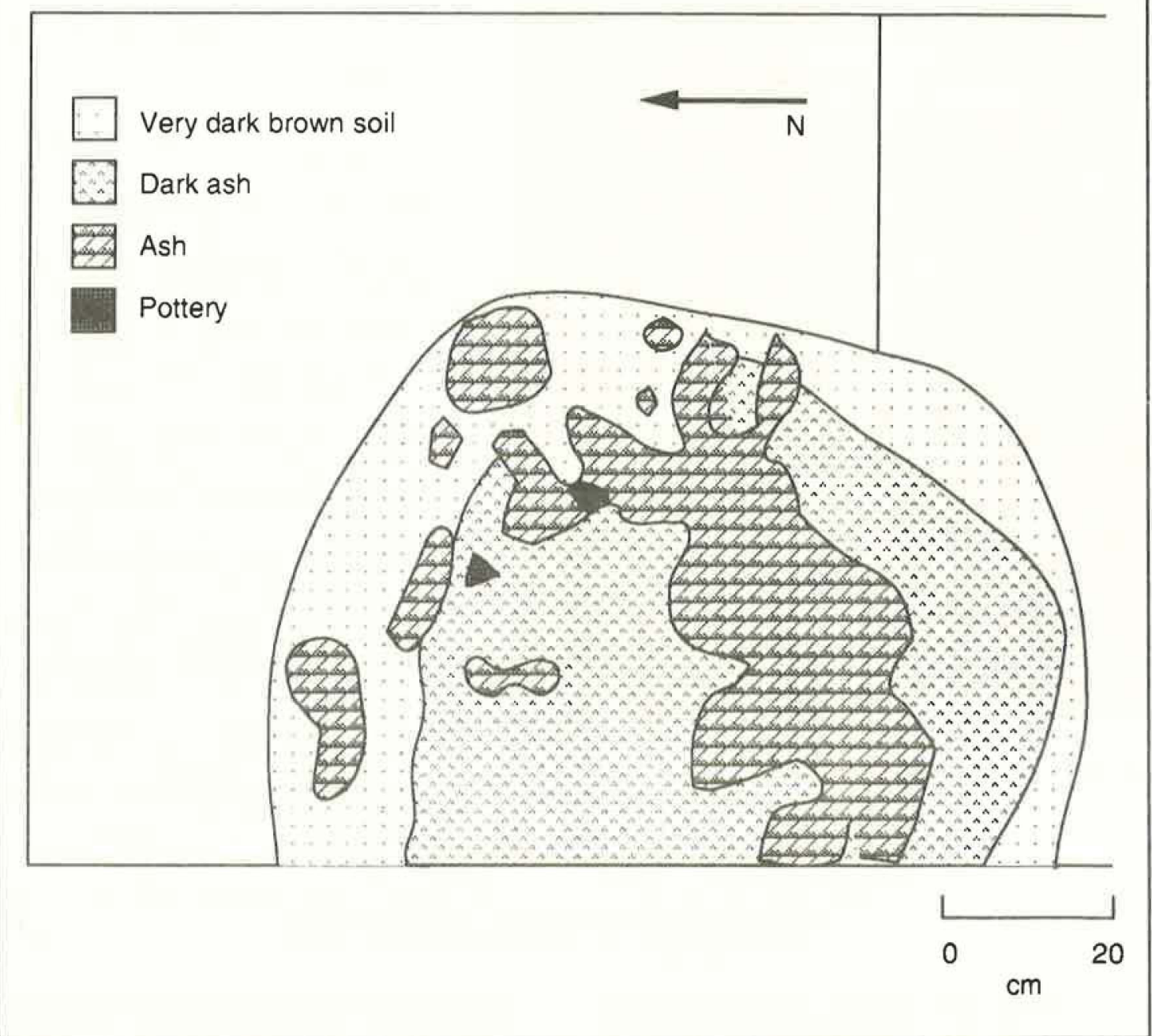

Figure 2. Plan View of Feature 19 (Hearth) in Block 1, Tyson Site (41SY92).

satisfy it, they make offerings to it of their first corn, tobacco, meat from the chase; and, in a word, all of their crops .. When in need they always appeal to the fire . .

And:
The fire the Tejas Indians have in their houses was brought from the house of their high priest. ... If the fire goes out they start immediately for the house 


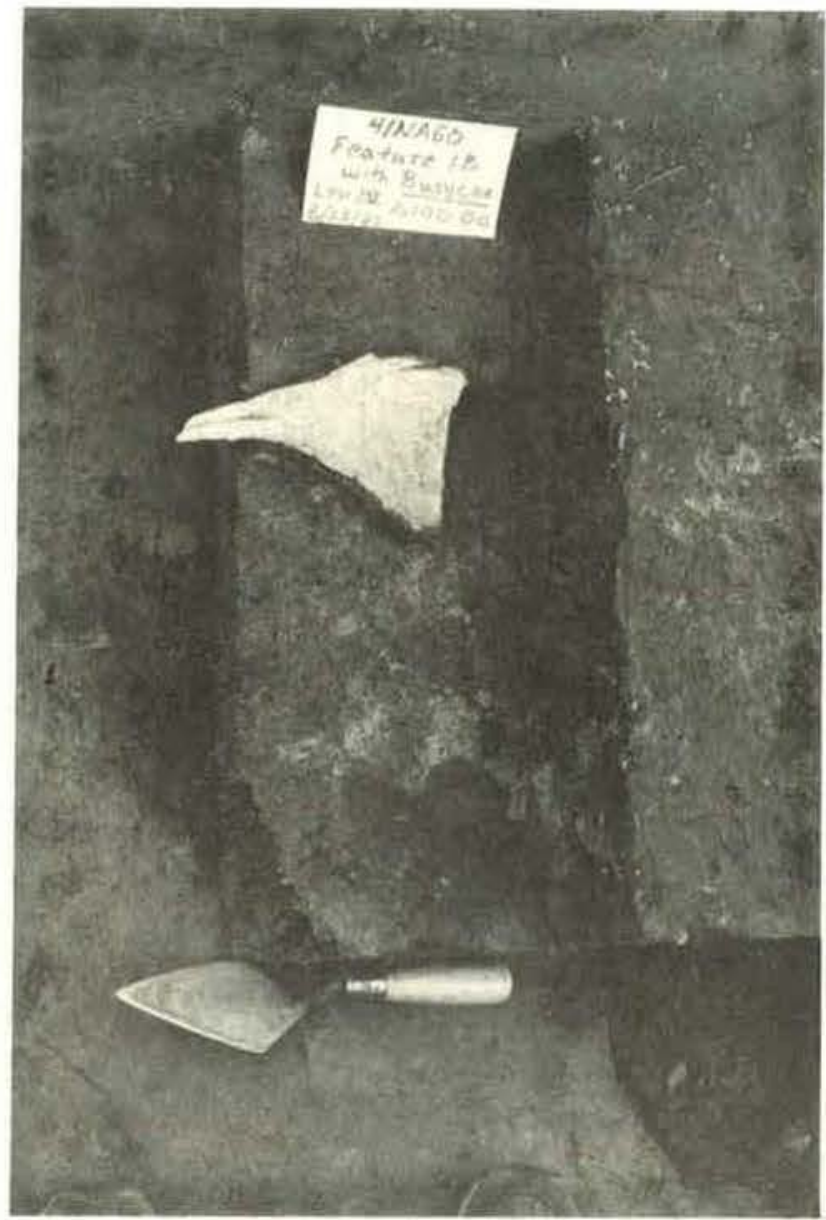

Figure 3. Busycon "Scoop" Artifact Offering in Central Hearth at Henry M Site (41NA60). of the priest to get new fire. It never goes out in the house of sacrifice. . .

In summary, then, the ethnohistoric record suggests that at least some Caddoan houses had a central hearth overlying a central posthole, and that fire had special significance binding each house to a perpetual fire at some religious center.

Parenthetically, the practice of placing offerings in a central hearth may be illustrated at the Henry $M$ Site (41NA60) along Bayou Loco in western Nacogdoches County (Middlebrook 1988). Henry $M$ is a small Allen phase farmstead probably dating to the early part of the 1700 s and contemporaneous with the nearby and better known Deshazo site (41NA27). Excavations to date have indicated the presence of at least one Caddoan house with a large, central posthole covered with the ash of a possible hearth. Interestingly, a well preserved Busycon sp. scoop, shaped by a groove and snap technology, was buried within the ash directly over the posthole (Figure 3). A valuable implement obtained through trade would not have likely been randomly tossed aside.

\section{ARCHEOLOGICAL FINDINGS}

In the sandy soils of East Texas, hearths are often evidenced by the presence of ash (perhaps mixed with charcoal) and, frequently, bumed clay. Ash is produced by the nearly complete burning of plant material and is composed of extremely alkaline potassium carbonates. Ash can reflect burning in place or the deposition of ashes from another location. Archeologically, ash may be found in several different contexts; a few examples include: (1) prepared clay hearths; (2) the scatter of embers along a living surface; (3) large ash filled pits that may have functioned for cooking, pottery making, or refuse disposal; (4) smaller ash and smudge pits possibly used in smoking animal products, "repelling insects", food preparation, or warming houses; (5) ash on floor of extended entranceway to ceremonial building; (6) central or peripheral fireplaces within ceremonial building; (7) fallen structural elements of a burned building; (8) an ash mound 
formed from the cumulative disposal of sacred ashes of a "fire temple"; and (9) the site of cremation burials.

Table 1 presents a summary of hearth, ash, and architectural structure data from an extensive sample of excavated Caddoan sites in Deep East Texas (DET; that portion of the Caddoan area south and east of the Sabine River). Table 2 displays for comparison a limited sample of sites in the nearby regions of Northeast Texas and Northwest Louisiana.

The DET data in Table 1 demonstrates the restricted nature of archeological information available concerning Caddoan house construction and site organization in the area. Initially, 121 structures excavated in the region appears to be an impressive number. However, $104(86 \%)$ of these structures were located within only $3(6 \%)$ of the 52 sites reviewed. Our perception of DET Caddoan architecture is dominated by, and therefore easily distorted by, findings at a single Early Caddo site (George C. Davis with 51 structures), a single recently excavated possible Middle Caddo site (Oak Hill Village with 42 structures), and a single Historic Caddo site (Deshazo with 9 structures). Only 11 (or $21 \%$ ) of the DET sites revealed hearths during excavation although other features containing ash or signs of burning were relatively common. While 24 $(48 \%)$ of the 50 hearths were shown to be "central" hearths within houses, all the central hearths were reported from just four DET sites: George C. Davis, Oak Hill Village, Bryan Hardy, and Henry $M$.

The central hearths found at the George C. Davis site in Cherokee County were under Mounds A and B and in the village areas. Newell and Krieger (1949:24) noted:

Fireplaces were found in 14 of the 34 (house) outlines, always approximately in the center. . . A large central posthole was present in more than half the outlines, usually at about the center of the fireplace when the latter was present. Some extended through the fireplace, but others had definitely been cut off before the fireplace was made ...

Spock (1977) carefully reanalyzed Davis site architectural features. She divided the 51 structures in her study into categories of "domiciles" and "special function structures". Interestingly, only 2 of the 30 domiciles had central hearths while 14 of the 21 special function structures had them. Twelve of the 16 central hearths at George C. Davis had associated center post (Spock 1977:30, Table 1).

The findings of Spock (1977) might suggest that at least in some Caddo mound sites the use of a central hearth was less likely in "habitations of the populace" than in more complex structures used in the religious or ceremonial life of the community. The observations at George C. Davis are not inconsistent with those of Webb (1959) who excavated eight houses in two Belcher site mounds. Seven of the eight houses had a central hearth or ash bed. Three were clay lined and one was found to have a central posthole beneath it. Large ash beds, possible the residue of ceremonial fires, were found around the interior periphery of Houses 6 and 7.

The construction of a large "ash mound" at the A.C. Saunders site is almost certainly related to the five "hearths" associated with a large building thought by A.T. Jackson to be a "fire temple" (Kleinschmidt 1982). The close relationship between central hearths and special use structures was also supported by Whiteside's (1958) excaation at the Bryan Hardy site, where he found a house with an extended entranceway and a central hearth under a low mound. The recent excavations at the Oak Hill Village site in Rusk County (Cruse 1995; Perttula, personal communication) are somewhat more problematic because the function of the site has not been fully established. Forty-two structures surround an apparent plaza. Four circular buildings (Structures $1,7,9$, and 17) contain central hearths over 
Table 1. Hearths Reported in ample of Deep East Texas Caddoan Studies.

\begin{tabular}{|c|c|c|c|c|c|c|c|}
\hline References & $\begin{array}{l}\text { Project } \\
\text { or Site }\end{array}$ & $\begin{array}{c}\text { \# of } \\
\text { Sites } \\
\text { tn } \\
\text { Study }\end{array}$ & $\begin{array}{l}\text { \# of } \\
\text { Site } \\
\text { with } \\
\text { Hearths }\end{array}$ & $\begin{array}{l}\text { \# of } \\
\text { Hearths } \\
\text { in } \\
\text { Study }\end{array}$ & $\begin{array}{c}\# \text { of } \\
\text { Central } \\
\text { Hearths }\end{array}$ & $\begin{array}{l}\# \text { of } \\
\text { Struc- } \\
\text { tures }\end{array}$ & Notes \\
\hline $\begin{array}{l}\text { Spock } 1977 \text { (in- } \\
\text { cludes Newell \& } \\
\text { Krieger } 1949 \text {; } \\
\text { Story } 1972\end{array}$ & $\begin{array}{l}\text { George C. } \\
\text { Davis }\end{array}$ & 1 & 1 & 16 & 10 & 51 & $\begin{array}{l}\text { Only } 2 \text { of } 30 \text { "domicile" } \\
\text { structures had central } \\
\text { hearths; } 14 \text { of } 21 \text { "special } \\
\text { structures" had them; } 12 \\
\text { structures had conter posts }\end{array}$ \\
\hline Fielda 1978 & $\begin{array}{l}\text { George C. } \\
\text { Davis }\end{array}$ & 1 & 1 & 2 & 0 & 0 & $\begin{array}{l}1 \text { hearth highly disturbed; } 2 \\
\text { ambiguous foatures with } \\
\text { charcoal \& burned clay not- } \\
\text { ed }\end{array}$ \\
\hline $\begin{array}{l}\text { Thurmond \& } \\
\text { Kleinuchmidt } \\
1979\end{array}$ & $\begin{array}{l}\text { Goorge C } \\
\text { Devis }\end{array}$ & 1 & 0 & 0 & 0 & 0 & $\begin{array}{l}\text { F193-1, large basin shaped } \\
\text { pit filled with much ash \& } \\
\text { refuse }\end{array}$ \\
\hline Creel 1979 & $\begin{array}{l}\text { George C } \\
\text { Davis }\end{array}$ & 1 & 1 & $1(?)$ & 0 & 1 & concentration of burned clay \\
\hline Story 1981 & $\begin{array}{l}\text { Goorge C. } \\
\text { Davis }\end{array}$ & 1 & 0 & 0 & 0 & $1(?)$ & $\begin{array}{l}\text { many charcoal filled pits; } \\
\text { F196-11 with in situ burning }\end{array}$ \\
\hline Story 1982 & Deshazo & 1 & 1 & 3 & 0 & 9 & $\begin{array}{l}\text { Hearth } 1 \text { unlikely to be cen- } \\
\text { tral, possibly remains of all } \\
\text { night bonfire in "annual re- } \\
\text { newal" ceremonies }\end{array}$ \\
\hline $\begin{array}{l}\text { Perttula } 1995 \\
\text { (personal com- } \\
\text { munication) }\end{array}$ & $\begin{array}{l}\text { Oak Hill } \\
\text { Villago } \\
\text { (41RK- } \\
214)\end{array}$ & 1 & 1 & 6 & 4 & 42 & $\begin{array}{l}4 \text { circular houses (Str. 1, 7, } \\
9,17 \text { ) had central hearths \& } \\
\text { center posts beneath; } 2 \text { rec- } \\
\text { tangular ones ( } \mathrm{Str} .38,39 \text { ), } \\
\text { hearths not over central posts }\end{array}$ \\
\hline Jolks 1965 & $\begin{array}{l}\text { McGee } \\
\text { Bend }\end{array}$ & 13 & 0 & 0 & 0 & 3 & $\begin{array}{l}17 \text { pits recorded from } 6 \\
\text { sites; } 9 \text { pits contained some } \\
\text { ash or burned clay }\end{array}$ \\
\hline $\begin{array}{l}\text { McClurkan et al } \\
1966\end{array}$ & $\begin{array}{l}\text { Toledo } \\
\text { Bend }\end{array}$ & 3 & 1 & 2 & 0 & 0 & $\begin{array}{l}\text { hoarth descriptions sound } \\
\text { more like trash filled pits }\end{array}$ \\
\hline Jansen 1968 & $\begin{array}{l}\text { Toledo } \\
\text { Bend }\end{array}$ & 4 & 1 & 1 & 0 & 0 & $\begin{array}{l}\text { James Pace site had "clay } \\
\text { lipped fire basin" }\end{array}$ \\
\hline Woodall 1969 & $\begin{array}{l}\text { Toledo } \\
\text { Bend }\end{array}$ & 2 & 1 & 5 & 0 & 0 & $\begin{array}{l}\text { Bison B, } 5 \text { circular charred } \\
\text { areas said to be outdoor } \\
\text { hearths }\end{array}$ \\
\hline $\begin{array}{l}\text { Bonham et al } \\
1973\end{array}$ & $\begin{array}{l}\text { Toledo } \\
\text { Bend }\end{array}$ & 3 & 1 & 4 & 0 & 3 & $\begin{array}{l}\text { 16SA17, small oval "pit } \\
\text { house; X41SY100, } 4 \text { hearths, } \\
\text { no clearly associated houses, } \\
\text { only limited area excavated }\end{array}$ \\
\hline $\begin{array}{l}\text { Anderzon et al } \\
1974\end{array}$ & $\begin{array}{l}\text { Lake Pal- } \\
\text { entine }\end{array}$ & 10 & 0 & 0 & 0 & 0 & Debro site had ash filled pit \\
\hline $\begin{array}{l}\text { Corbin et al } \\
1984\end{array}$ & $\begin{array}{l}\text { Washing- } \\
\text { ton } \\
\text { Square }\end{array}$ & 1 & 0 & 0 & 0 & 2 & $\begin{array}{l}\text { Unusual collapsed structure } \\
\text { under mound; pit encircled } \\
\text { with postholes; no hearths }\end{array}$ \\
\hline $\begin{array}{l}\text { Corbin et al } \\
1980\end{array}$ & $\begin{array}{l}\text { Mission } \\
\text { Dolores }\end{array}$ & 1 & 1 & 1 & 0 & $4 ?$ & $\begin{array}{l}\text { Feature } 6 \text { (hearth) eroding } \\
\text { from ditch; all strucutral fea- } \\
\text { tures appoar related to mis- } \\
\text { sion }\end{array}$ \\
\hline
\end{tabular}


Table 1 (continued). Hearth Reported in a Sample of Deep East Texas Caddoan Studies.

\begin{tabular}{|c|c|c|c|c|c|c|c|}
\hline References & $\begin{array}{l}\text { Project } \\
\text { or Site }\end{array}$ & $\begin{array}{l}\text { \# of } \\
\text { Sites } \\
\text { in } \\
\text { Study }\end{array}$ & $\begin{array}{l}\text { \# of } \\
\text { Sites } \\
\text { with } \\
\text { Hearths }\end{array}$ & $\begin{array}{l}\text { \# of } \\
\text { Hearths } \\
\text { in } \\
\text { Study }\end{array}$ & $\begin{array}{c}\text { \# of } \\
\text { Central } \\
\text { Hearths }\end{array}$ & $\begin{array}{l}\text { \# of } \\
\text { Struc- } \\
\text { tures }\end{array}$ & Notes \\
\hline $\begin{array}{l}\text { Corbin et al } \\
1978\end{array}$ & Chaya & 1 & 0 & 0 & 0 & 0 & $\begin{array}{l}\text { Natural depression apparontly } \\
\text { enlarged for use an "midden" }\end{array}$ \\
\hline $\begin{array}{l}\text { Kenmotsu } \\
1992\end{array}$ & Mayhew & 1 & 0 & 0 & 0 & 0 & $\begin{array}{l}\text { Very shallow cultural horizon } \\
\text { with high numbers of small } \\
\text { sherds }\end{array}$ \\
\hline $\begin{array}{l}\text { Middlobrook } \\
1988\end{array}$ & $\begin{array}{l}\text { Henry M } \\
\text { (41NA60) }\end{array}$ & 1 & 1 & 1 & 1 & 1 & $\begin{array}{l}\text { Conch shell "offering" in ash } \\
\text { of central hoarth over centor } \\
\text { post; pouthole filled with ash }\end{array}$ \\
\hline Jones 1968 & $\begin{array}{l}\text { "Kinsloe } \\
\text { Focus" }\end{array}$ & 7 & 0 & 0 & 0 & 0 & $\begin{array}{l}\text { Exoavation focus on burials } \\
\text { and a fow trash pita }\end{array}$ \\
\hline $\begin{array}{l}\text { Kleinschmidt } \\
1982\end{array}$ & $\begin{array}{l}\text { A C } \\
\text { Saundera }\end{array}$ & 1 & 1 & 5 & 0 & 1 & $\begin{array}{l}\text { Large house thought to be "fire } \\
\text { temple" \& associated "arh } \\
\text { mound" }\end{array}$ \\
\hline $\begin{array}{l}\text { Whiteside } \\
1958 \text { (letter in } \\
\text { TARL files) }\end{array}$ & $\begin{array}{l}\text { Bryan } \\
\text { Hardy }\end{array}$ & 1 & 1 & 3 & 3 & 3 & $\begin{array}{l}\text { Avocational excavation; one of } \\
\text { houses has extended ontrance- } \\
\text { way \& is located under a low } \\
\text { mound }\end{array}$ \\
\hline 23 sTUDIES & TOTALS & s2 & 11 & 50 & 24 & 121 & \\
\hline
\end{tabular}

central postholes. Two rectangular buildings (Structures 38 and 39 ), probably related to an earlier occupation of the site, had hearths not located centrally to the structures and not over posts. The only central hearth in the reviewed DET studies that seems to be completely unrelated to a possible ceremonial or special function site is the one excavated at the Henry M site (Middlebrook 1988).

Most of the remaining reports in this review failed to associate hearths with houses due to the small areal extent of excavation or other factors negatively influencing posthole detection. This is certainly not the case, however, at the extensively studied Deshazo site in Nacogdoches County, where three hearths were uncovered in the vicinity of overlapping structures in Unit 1 (Story 1982). Hearth 2 was likely a small utilitarian fireplace about midway between the center post and the exterior wall. Hearth 3 is a feature with a posthole underneath, but not clearly associated with any structure. Its use is uncertain. Hearth 1 , near several center posts, may not have been associated with any of the three houses. Carolyn Good (1982) speculated that this feature may well have represented the locale of an all-night bonfire in the "annual renewal" ceremonies described by early Spanish writers. Belcher site mounds. Seven of the eight houses had a central hearth or ash bed. Three were clay lined and one was found to have a central posthole beneath it.Large ash beds, possibly the residual of ceremonial fires, where found around the interior periphery of Houses 6 and 7.

The construction of a large "ash mound" at the A. C. Saunders site is almost certainly related to the five "hearths" associated with a large building thought by A. T. Jackson to be a "fire temple" (Kleinschmidt 1982). The close relationship between central hearths and special use structures also be supported by Whiteside's (1958) excava- 
Table 2. Hearths Reported in Comparative Studies from Northeast Texas and Northwest Louisiana.

\begin{tabular}{|c|c|c|c|c|c|c|c|}
\hline Reference & $\begin{array}{l}\text { Project } \\
\text { or Site }\end{array}$ & $\begin{array}{l}\text { \# of } \\
\text { Sites } \\
\text { in } \\
\text { Study }\end{array}$ & $\begin{array}{c}\text { \# of } \\
\text { Sites } \\
\text { with } \\
\text { Hearths }\end{array}$ & $\begin{array}{l}\text { \# of } \\
\text { Hearths } \\
\text { in } \\
\text { Study }\end{array}$ & $\begin{array}{c}\text { \# of } \\
\text { Central } \\
\text { Hearths }\end{array}$ & $\begin{array}{l}\# \text { of } \\
\text { Struc- } \\
\text { tures }\end{array}$ & Notes \\
\hline $\begin{array}{l}\text { Bruseth \& } \\
\text { Perttula } 1981\end{array}$ & Lake Fork & 9 & 7 & 9 & ? & 4 & $\begin{array}{l}\text { Most house patterns near hearths } \\
\text { not discernible }\end{array}$ \\
\hline $\begin{array}{l}\text { Jolks \& } \\
\text { Tunnell } 1959\end{array}$ & Herroun & 1 & 1 & 3 (or 4) & 3 (or 4 ) & 4 & $\begin{array}{l}\text { Houses } 1 \text { \& } 2 \text { superimposed; } \\
\text { looters' pit disrupted area of con- } \\
\text { tral hearth(s) }\end{array}$ \\
\hline $\begin{array}{l}\text { Skinner et al } \\
1969\end{array}$ & $\begin{array}{l}\text { Sam } \\
\text { Kaufman } \\
\text { (Roitsch) }\end{array}$ & 1 & 1 & 3 & 1 & 3 & $\begin{array}{l}2 \text { hearths in House } 3 \text { may havo } \\
\text { been "burned superstructure" (p } \\
21 \text { ) }\end{array}$ \\
\hline $\begin{array}{l}\text { Brusth at at } \\
\text { 1991; Martin } \\
\text { in Brusoth } \\
1992\end{array}$ & Roitsch & 1 & 1 & 3 & 0 & $?$ & $\begin{array}{l}\text { Block I in East Mound had large } \\
\text { pit with ashes noers base; Block } \\
\text { III had hearth; Block IV had } 2 \\
\text { hearths; "Special Forces" had } \\
\text { large ash pit }\end{array}$ \\
\hline Perino 1983 & $\begin{array}{l}\text { Bob } \\
\text { Williems }\end{array}$ & 1 & 1 & 1 & 0 & $1 ?$ & $\begin{array}{l}\text { Description limited; focus on } \\
\text { cernetery }\end{array}$ \\
\hline Wobb 1959 & Belcher & 1 & 1 & 33 & 7 & 8 & $\begin{array}{l}7 \text { central hearths ( } 3 \text { clay lined, } 3 \\
\text { central posts beneath), ash bods } \\
\text { appeared associated with cooking } \\
\text { ( } 3-5 \text { hoarths), entranceways ( } 3 \\
\text { beds), and ceremonial fires in } \\
\text { Houses } 6 \& 7 \text { ( } 18 \text { ash beds) }\end{array}$ \\
\hline Webb 1983 & $\begin{array}{l}\text { Bossier } \\
\text { Focus }\end{array}$ & 4 & 2 & 3 & 0 & 1 & $\begin{array}{l}\text { Montgomery had probable } \\
\text { hearth; Werner site had } 2 \text { ash } \\
\text { beda near each of double circular } \\
\text { walla }\end{array}$ \\
\hline $\begin{array}{l}\text { Browington } \\
\text { et al } 1995\end{array}$ & $41 \mathrm{MX5}$ & 1 & 0 & 0 & 0 & 3 & \\
\hline $\begin{array}{l}\text { Thoman ot al } \\
1980\end{array}$ & Henne & 1 & 1. & I & 1 & 6 & $\begin{array}{l}\text { Structure } 2 \text { found to have contral } \\
\text { hearth; } 3 \text { "cooking pits" with ash } \\
\text { or fired clay found in } 3 \text { struc- } \\
\text { tures; smudge pits }\end{array}$ \\
\hline Kolly 1994 & $\begin{array}{l}\text { McLel- } \\
\text { land, Joo } \\
\text { Clark }\end{array}$ & 2 & 2 & 2 & 2 & 3 & $\begin{array}{l}1 \text { of } 2 \text { houses at McLelland had } \\
\text { central hearth and post; } 1 \text { house } \\
\text { at Joe Clark had same }\end{array}$ \\
\hline $\begin{array}{l}\text { Trubowitz } \\
1984\end{array}$ & $\begin{array}{l}\text { Ceder } \\
\text { Grove }\end{array}$ & 1 & 0 & 0 & 0 & 3 & $\begin{array}{l}\text { Feature } 18 \text { in Structure } 1 \text { possi- } \\
\text { ble hearth, baking pit, or pit for } \\
\text { hot coals to warm house; F20 } \\
\text { had ash from "burning on the } \\
\text { spot" }\end{array}$ \\
\hline$\stackrel{11}{\text { STUDIES }}$ & & 23 & 17 & 59 & 15 & 36 & \\
\hline
\end{tabular}


tion at the Bryan Hardy site where he found a house with an extended entranceway and a central hearth under a low mound. The recent excavations at the Oak Hill Village site in Rusk County (Cruse 1995; Perttula, personal communication; ed. note: see pp. 23-25) are somewhat more problematic because the function of the site has not been fully established. Forty two structures surround an apparent plaza. Four circular buildings (Structures 1, 7, 9, and 17) contain central hearths over central postholes. Two rectangular buildings (Structures $38 \& 39$ ) probably related to an earlier occupation of the site had hearths not located central to the struc-tures and not over posts. The only central hearth in the reviewed DET studies that seems to be completely unrelated to a possible ceremonial or special function site is the one excavated at the Henry $M$ site (Middlebrook, 1988).
Most of the remaining reports in this review failed to associate hearths with houses due to the small areal extent of excavation or other factors negatively influencing posthole detection. This is certainly not the case, however, at the extensively studied Deshazo site in Nacogdoches County where three hearths were uncovered in the vicinity of overlapping structures in Unit 1 (Story 1982). Hearth 2 was likely a small utilitarian fireplace about midway between the center post and the exterior wall. Hearth 3 is a feature with a posthole underneath, but not clearly associated with any structure. Its use is uncertain. Hearth 1, near several center posts, may not have been associated with any of the three houses. Carolyn Good (1982) speculated that this feature may well have represented the locale of an all-night bonfire in the "annual renewal" ceremonies described by early Spanish writers.

\section{CONCLUSIONS}

In summary, the reviewed archaeological findings in Deep East Texas Caddoan sites, modestly but inconsistently, support the predictions regarding hearths based on the ethnohistoric record. Major gaps still exists in our understanding of fireplaces. Hearths are certainly not created equal; specifically, they vary in size, shape, location, preparation, function, duration of use, and contents. There may be limitations to applying information about other Caddoan hearths to the Tyson site. Nevertheless, our working hypothesis that Feature 9 represents a central hearth is appealing because of its large size, associations with large postholes, and proximity to other likely interior house features. The structure here may have been the residence of an important local Caddoan political or religious figure given the very elaborate grave offerings associated with two juvenile burials adjacent to Feature 9 (Middlebrook 1994). Careful analysis of the faunal, paleobotanical, and ceramic contents of the hearth is scheduled and may reveal more clues to Feature 9's function.

\section{ACKNOWLEDGMENTS}

The authors wish to thank Tim Perttula for his ongoing support and sharing of information and Alan Skinner for his kind expression of encour- agement after this paper was initially read at the 1994 East Texas Archeological Conference. 


\section{REFERENCES}

Anderson, K.M., K. Gilmore, O.F. McCormick III, and E.P. Morenon 1974 Archaeological Investigations at Lake Palestine, Texas. Contributions in Anthropology 11. Southern Methodist University, Dallas.

Benham, B. L., H. L. Miller, and J. V. Sciscenti

1973 Archeological Research in the Toledo Bend Reservoir. Archeological Research Program, Research Report 24. Southern Methodist University. Dallas.

Bolton, Herbert E.

1987 The Hasinais: Southern Caddoans as Seen by the Earliest Europeans. Edited and introduced by Russell M. Magnaghi.

University of Oklahoma Press. Norman.

Brewington, Robbie L., J. E. Dockall, and H. J. Shafer

1995 Archeology of 41MX5: A Late Prehistoric Caddoan Hamlet in Morris County, Texas. Reports of Investigations 1. Center for Environmental Archeology, Texas A \& M University. College Station.

Bruseth, James E.

1991 TAS Field School, The Sam Kaufman Site (41RR16), Red River County, Texas. Texas Archeology 35(2):3f.

1992 The 1992 Field School: Soggy but Successful. Texas Archeology; 36(3):1f.

Bruseth, J.E., and T. K. Perttula 1981 Prehistoric Settlement Patterns at Lake

Fork Reservoir. Texas Antiquities Committee, Texas Antiquities Permit Series, Report 2.

Texas Historical Commission, Austin.

Chabot, F. C.

1930 Indian Excerpts (Translation of Memorias for the History of Texas) by Father
Morfi. Naylor Printing Co., San Antonio.

Corbin, J. E., T. C. Alex, and A. Kalina 1980 Mission Delores do los Ais. Stephen F. Austin State University Papers in Anthropology 2. Nacogdoches.

Corbin, J. E., J. M. Studer, L. Numi 1978 The Chaya Site. Stephen F. Austin State University Papers in Anthropology 1. Nacogdoches.

Corbin, J. E., D, Kisling, S. Oakes, and J. P. Hart

1984 Archeological Investigations of the Washington Square Mound Site (41NA49). Stephen F. Austin State University Papers in Anthropology 5. Nacogdoches.

Creel, Darrell G.

1979 Archeological Investigations at the George C. Davis Site, Cherokee County, Texas, Summer 1978. Texas Antiquities Permit Series 1. Texas A \& M University, College Station and Texas Antiquities Commission, Austin.

Cruse, J. Brett

1995 Archeological Investigation of the Oak Hill Village Site (41RK214): A Middle Caddoan Settlement in Rusk County, Texas. Paper presented to the 1995 Caddo Conference, Austin, Texas; March 24, 1995.

Fields, Ross C.

1978 Report on the 1977 Investigations at the George C. Davis Site, Caddoan Mounds State Historic Site, Cherokee County, Texas, Texas Archeological Research Laboratory, University of Texas, Austin.

Good, Carolyn E.

1982 Analysis of Structures, Burials, and

Other Cultural Features. In The Deshazo Site, Nacogdoches County, Texas, Volume 1, edit- 
ed by Dee Ann Story, pp. 51-112. Permit Series 7. Texas Antiquities Committee, Austin.

Hatcher, Mattie A.

1927 Descriptions of the Tejas or Asinai Indians, 1691 - 1722. Southwestern Historical Quarterly 31(2):177.

Jackson, A. T.

1936 A Perpetual Fire Site. Bulletin of the Texas Archeological Society 8:134-176.

Jelks, Edward B.

1965 The Archeology of the McGee Bend Reservoir, Texas. Ph.D. Dissertation, Department of Anthropology, University of Texas, Austin.

Jensen, Harald P.

1968 Archeological Investigations in the Toledo Bend Reservoir 1966 - 1967. Southern Methodist University and National Park Service. Dallas.

Jones, Buddy C.

1968 The Kinsloe Focus: A Study of Seven Historic Caddoan Sites in Northeastern Texas. Master's Thesis, Department of Anthropology, University of Oklahoma.

Kelley, D. B.

1994 The McLelland and Joe Clark Sites: Protohistoric and Historic Caddoan Farmsteads in Southern Bossier Parish, Louisiana. Coastal Environments, Inc., Baton Rouge.

Kenmotsu, N. A.

1992 The Mayhew Site: A Possible Hasinai Farmstead, Nacogdoches County, Texas. Bulletin of the Texas Archeological Society 63:135-174.

Kleinschmidt, Ulrich $\mathrm{K}$. W.

1982 Review and Analysis of the A.C. Saunders Site, 41AN19, Anderson County, Texas. Master's thesis, Department of
Anthropology, University of Texas, Austin.

McClurkan, B.B., W.T. Field, and J.N.

Woodall

1966 Excavations in Toledo Bend Reservoir, 1964-1965. Papers of the Texas Archeological Salvage Project 8, Texas Archeological Salvage Project, University of Texas, Austin.

Middlebrook, Tom A.

1988 Preliminary Report on Investigations at the Henry Mast Site (41NA60). Paper presented to the 30th Caddo Conference, Dallas, Texas. March 13, 1988.

1993 Radiocarbon Dates from the Tyson Site (41SY92). Caddoan Archeology Newsletter 3(4):2-8.

1994 An Update of Archeological Investigations at the Tyson Site (41SY92). Journal of Northeast Texas Archeology 3.

Newell, H. Perry, and Alex D. Krieger 1949 The George C. Davis Site, Cherokee County, Texas. Memoir 5. Society for American Archeology.

Perino, Gregory

1983 Archeological Research at the Bob Williams Site, Red River County, Texas. Potsherd Press, Museum of the Red River. Idabel, Oklahoma.

Skinner, S. A., R. K. Harris, and K. M. Anderson (Editors)

1969 Archeological Investigations at the Sam Kaufman Site, Red River County, Texas. Southern Methodist University, Contributions in Anthropology 5. Dallas.

Story, Dee Ann

1972 A Preliminary Report of the 1968, 1969, and 1970 Excavations at the George C. Davis Site, Cherokee County, Texas: A Report of Field Research Conducted under National Science Foundation Grants (GS2573 and 3200) and Interagency Contracts between 
University of Texas at Austin, Texas Building Commission, and the Texas Historical Committee. University of Texas, Austin.

Story, Dee Ann (Editor)

1981 Archeological Investigations at the George C. Davis Site, Cherokee County, Texas: Summers of 1979 and 1980 . Texas Archeological Research Laboratory Occasional Papers 1. University of Texas, Austin.

1982 The Deshazo Site, Nacogdoches County, Texas, Vol 1. Texas Antiquities Permit 7. Texas Antiquities Committee, Austin.

Swanton, John R.

1942 Source Material on the History and Ethnology of the Caddo Indians. Bulletin 132. Bureau of American Ethnology, Smith sonian Institution, Washington, D.C.

Thomas, P. M., L. J. Campbell, and S. R. Ahler

1980 The Hanna Site: An Alto Village in Red River Parish. Louisiana Archeology 5.

Thurmond, J. Peter, and Ulrich Kleinschmidt 1979 Report on the Fall 1978 Investigations at the George C. Davis Site Caddoan Mounds
State Historic Site, Cherokee County, Texas. Texas Archeological Research Laboratory, University of Texas. Austin.

Trubowitz, Neal L. (editor) 1984 Cedar Grove: An Interdisciplinary Investigation of a Late Caddo Farmstead in the Red River Valley. Arkansas Archeological Survey Research Series 23. Fayetteville.

Webb, Clarence $\mathrm{H}$.

1959 The Belcher Mound, a Stratified Caddoan Site in Caddo Parish, Louisiana. Society for American Archeology Memoirs 16.

Whiteside, Sam

1958 Letter to E. Mott Davis. On file, Texas Archeological Research Laboratory.

Woodall, J.N.

1969 Cultural Ecology of the Caddo. Ph.D. Dissertation, Department of Anthropology, Southern Methodist University, Dallas.

Wyckoff, Don G., and Timothy G. Baugh 1980 Early Historic Hasinai Elites: A Model for the Material Culture of Governing Elites. Midcontinental Journal of Archeology 5:225-288. 